\title{
The Effect of Problem Based Learning Model on Problem Solving Ability Student
}

\author{
Nurkhairunnisa Siregar ${ }^{1 *}$ \\ Student of Postgraduate, Basic \\ Education $^{1 *}$ \\ Universitas Negeri Medan \\ Medan, Indonesia \\ Email: \\ nurkhairunnisa19@yahoo.co.id
}

\author{
$\operatorname{Asmin}^{2}$ \\ Lecturer of Postgraduate Unimed ${ }^{2}$ \\ Universitas Negeri Medan, \\ Medan, Indonesia
}

\author{
Kms. M. Amin Fauzi ${ }^{3}$ \\ Lecturer of Postgraduate Unimed ${ }^{3}$ \\ Universitas Negeri Medan, \\ Medan, Indonesia
}

\begin{abstract}
This study aims to determine the effect of the Problem Based Learning model on students' mathematical problem solving abilities. In addition, this study also looked at the interaction between learning and gender on students' mathematical problem solving abilities. This research was a quasi-experimental study. The population in this study consisted of all students in junior high school (SMP) 7 Padangsidimpuan totaling 423 students. The study sample consisted of 46 students, namely 23 students in grade VIII-3 and 23 students in grade VIII-6. Data analysis was performed with two-way ANOVA using SPSS version 21.0. The results of this study indicate that there is the effect of the Problem-Based Learning model on mathematical problem solving ability of students. In addition the result also show that there is no interaction between learning and gender on students' mathematical problem solving abilities.
\end{abstract}

Keywords-Problems Solving Ability; Gender; Problem Based Learning Model

\section{INTRODUCTION}

Globalization require education to evolve better in accordance with the provisions that are fundamental to the development of science and technology. These changes also have an impact on the mathematics curriculum in Permendikbud Number 58 of 2014 which explains that the purpose of mathematics learning in general requires that students have the ability to solve mathematical problems. This is in line with Vettleson's opinion which states that the use of problem solving skills in mathematical disciplines has a very important and most influential influence on the development of the times [1].

Furthermore, the importance of mathematical problem solving skills was also expressed by Yavuz, Arslan, and Gulten who stated that problem solving abilities are the skills most needed for the maintenance of the human generation, because these abilities are not only needed to solve problems in mathematics but also required students to complete their problems in everyday life [2]. A person who has the ability to solve problems properly will be able to utilize information effectively too.
This is in line with the Marchis's opinion which states that students mathematical problem solving abilities are important because the results show that problem solving abilities have a positive influence on students 'attitudes in mathematics, so that it affects students' confidence in their own mathematical abilities [3]. Thus, problem solving ability is an ability that must be possessed by students to go through all processes in developing their knowledge.

The problem solving indicators in this study are: (1) the ability of students to understand the problem (write down what is known and asked); (2) the ability to plan problem solving (choosing and arranging the right way to solve problems); (3) the ability to do calculations correctly; (4) the ability to reexamine solutions to problems that have been resolved.

But in reality based on the results of preliminary studies, the mathematical problem solving skill of eighth grade students of junior high school (SMP) 7 Padangsidimpuan is still low. The inability of 23 students to fulfill four indicators of problem solving ability in the question is presented in the form of percentage. On the first indicator, $33 \%$ of students have not been able to disclose information from the problem. On the second indicator, $82 \%$ of students have not been able to understand the problem and formulate a strategy. Then on the third indicator there are $66 \%$ of students who have not been able to apply the concept to the problem. Finally, in the fourth indicator, there are $87 \%$ of students who have not been able to check the answers. So it can be concluded that students' mathematical problem solving abilities are categorized as still low.

That is consistent with the preliminary study from Minarni's research which states that in determining the mathematical model students can do it well, but students face difficulties in the aspect of problem solving planning and explain the solution to the problems in the problem [4].

To solve this problems, the teacher can make changes in the teaching and learning process, where the teacher is required to reflect active, innovative and fun learning. Mathematical problem solving skills and learning independence of students can be trained and developed when a teacher can choose an approach, model, method, or learning strategy that are suitable and in accordance with the material, 
situation and condition of students in learning. One alternative learning model that is more oriented to improve students' mathematical problem solving abilities is to apply the Problem Based Learning model.

The Problem Based Learning model was introduced by McMaster University Medical School in Canada in the late 1960s, as a teaching and learning approach, and included in the literature [5]. According to Surya and Syahputra the core of the Problem Based Learning (PBL) model is to describe the learning environment where the problem is a stepping stone of learning. That is, this learning begins with a problem that must be resolved, and the proposed problem is designed in such a way that students can be independent in learning to gain new knowledge before they can solve problems [6].

Mustafa, et al also stated that PBL models play an important role in developing cognitive and affective domains and students' skills to solve mathematical problems, because through these problem solving activities can encourage students to acquire new knowledge before they can solve the given problem [7]. Thus, this PBL model can help contextualize knowledge and transfer student knowledge.

The syntax of the Problem Based Learning model in this study was taken from opinion of Arends [8]: (1) providing an introduction to the problem to students; (2) organizing students to investigate problems; (3) assisting independent and group investigations; (4) develop and present the results of problem solving; (5) analyze and evaluate the problem solving process.

The difference between this study and previous research found out the interaction between learning models (PBL and conventional) with gender (male and female) on students' mathematical problem solving abilities. Whether there is a gender gap in mathematical achievement has long been an interesting topic for researchers. According to Papalia and Ruth, the male brain structure is different from that of women, and he also stated that boys give better results than women in math tests [9]. However, finding from Kaymakamoğlu's research show that female and male students' perceptions differ only for 'thinking approaches' and' evaluative approaches'. Female students feel more competent in interpersonal problems, especially problem solving skills by themselves following "thinking approaches" and "evaluative approaches" compared to male students [10]. This is as the background of the researcher to be interested in conducting research on the effect of PBL on students' mathematical problem solving abilities that are related to student gender.

The formulation of the research problem is (1) Is there the effect of Problem Based Learning model on the mathematical problem solving ability of students, (2) Are there interactions between learning models with gender on students' mathematical problem solving abilities.

\section{RESEARCH METHOD}

The type of research used in this study is quasiexperimental. This research was conducted at junior high school (SMP) 7 Padangsidimpuan located at Jalan Raya Angkola Julu, Joring Village Lombang, Padangsidimpuan
District Angkola Julu. The population in this study consisted of all students in SMP 7 Padangsidimpuan totaling 423 students. The study sample consisted of 46 students, namely 23 students in grade VIII-3 (class control) and 23 students in grade VIII-6 (class experiment). The research design used was Pre Test Post Control Group Design Test. The design or design of the research was carried out as follows [11]:

$\begin{array}{cccc}\text { Experiment } & \mathrm{O}_{1} & \mathrm{X} & \mathrm{O}_{2} \\ \text { Control } & \mathrm{O}_{1} & - & \mathrm{O}_{2}\end{array}$

With $\quad \mathrm{X}$ : Problem Based Learning Model

$\mathrm{O}_{1}$ : Pretest problem solving ability students

$\mathrm{O}_{2}$ : Postest problem solving ability students

The data collection instrument in this study was to use the students' mathematical problem solving ability test which before being used the instrument would be assessed by a competent validator which included mathematics lecturers and teachers in the school and tested against respondents outside the sample class. Data analysis techniques in this study use descriptive statistics and inferential statistics. The data in this study consisted of normality testing, homogeneity testing, and hypothesis testing. Testing all statistical hypotheses in this study using the Two-Path ANOVA test with the help of SPSS 21.0 .

\section{RESULT AND DISCUSSION}

The results of posttest descriptive analysis of problem solving abilities of students in the experimental class and control class can be seen through the mean and the standard deviation. The average and standard deviation of problem solving ability through the two tests are presented in Table 1:

TABle 1. Problem Solving ABILITy Test’s Result

\begin{tabular}{|c|c|c|c|}
\hline \multicolumn{3}{|c|}{ Learning } \\
\hline \multicolumn{2}{|c|}{ PBL (Eksperimen) } & \multicolumn{2}{c|}{ Conventional (Kontrol) } \\
\hline N & 23 & Mean & 23 \\
\hline Mean & 29,78 & 19,35 \\
\hline $\begin{array}{c}\text { Standart } \\
\text { Deviation }\end{array}$ & 6,742 & $\begin{array}{c}\text { Standart } \\
\text { Deviation }\end{array}$ & 7,866 \\
\hline
\end{tabular}

Based on Table 1, We can see that the average postproblem solving ability of students who are subjected to the Problem Based Learning model is higher than that of students who obtain conventional learning. This finding is in line with Sahyar and Firti's research which states that problem solving ability in PBL class for AQ students group is higher on average than students' problem solving ability in conventional class for average AQ group [12]. 


\section{A. Hypothesis 1}

The results of the statistical hypothesis test for the formulation of problem 1 obtained that $\mathrm{F}_{\text {count }} 22,008$ and sig. 0,000 . In this case $F_{\text {table }}$ for $\mathrm{df}$ numerator $=1$ and $\mathrm{df}$ denominator $=42$ is obtained by using interpolation of 4.07 . It can be seen that $\mathrm{F}_{\text {count }}(=22,008)>\mathrm{F}_{\text {table }}(=4,07)$ and Sig. $(=$ $0,000)<(=0,05)$, so there is enough evidence to make a decision that $\mathrm{H}_{0}$ is rejected and $\mathrm{H}_{\mathrm{a}}$ is accepted. Thus it can be concluded that there is the effect of Problem Based Learning model on problem solving ability of students.

The results of this study also have similarities with the results of previous studies [13] which states that the application of PBL models can improve students' problem solving abilities in class IX Muhammadiyah 4 Junior High School Malang. Students can assess their own abilities as better problem solvers because in the PBL model students must find solutions and they will also be trained in handling problems, because the problems presented in the learning process reflect the real problems faced in everyday life. With sustainable practice, students' problem solving skills will be more developed.

The difference between the results obtained from the experimental class and the control class is caused by the learning that the characteristics of the Problem Based Learning model are certainly different from conventional learning. In conventional learning, mathematics material is explained by the teacher accompanied by examples and giving exercises of mathematical questions in the form of numbers without meaning. Problems that do not really need problem solving thinking activities, so that in solving math problems students only imitate and follow the example of the teacher when solving the problem. This is in line with Sahyar's explanation [14] in conventional learning, students tend to be passive in class because learning that is received only learns one way and is less faced with problems and students are less freed in developing their own understanding. Thus, when students are faced with mathematical problems that require high-level thinking activities, students will not be able to make students' problem solving skills low.

Whereas in the Problem Based Learning model students are presented with the problems that have been provided in the LKS, so student need to investigate problems, compile and present the results of problem solving, and collaborate in solving problems. The problem provided contains four questions in the form of problem solving indicators, including understanding the problem, planning problem solving, performing calculations and checking again. By applying the Problem Based Learning model continuously in math class, it is assisted by the provision of worksheets that support the Problem Based Learning model and familiarize students to solve various authentic problems so that can result in the Problem Based Learning model more influence on mathematical problem solving abilities students.

\section{B. Hypothesis 2}

Results The problem solving ability tests obtained in the form of scores are grouped by gender, namely Men (L) and
Women (P), it aims to see the interaction between learning models with gender on students' mathematical problem solving abilities. The results of the calculation of the problem solving ability in question can be seen in Table 2 :

Table 2. Classification Of Problem Solving Ability Based On Gender STUDENTS

\begin{tabular}{|c|c|c|c|}
\hline Group & Gender & $\sum$ & Mean \\
\hline \multirow{2}{*}{ Experiment } & $\mathrm{L}$ & 13 & 30,69 \\
\cline { 2 - 4 } & $\mathrm{P}$ & 10 & 28,60 \\
\hline \multirow{2}{*}{ Control } & $\mathrm{L}$ & 13 & 19,92 \\
\cline { 2 - 4 } & $\mathrm{P}$ & 10 & 18,60 \\
\hline
\end{tabular}

The results showed that the mathematical problem solving skills of male and female students taught with the Problem Based Learning model were higher than the mathematical problem solving skills of male and female students taught with conventional learning. In other words, the Problem Based Learning model is suitable to be applied rather than conventional learning for both male and female students.

Nevertheless, the average mathematical problem-solving ability of male students is higher than for females. This is according to Cooper, Bailey and Briggs caused by stereotypical factors, motivation, ways of thinking, confidence, and positive attitudes towards mathematics that make male students superior to women [15].

The results of the two-way ANOVA calculation for the interaction of learning with gender on mathematical problem solving abilities of students also showed sig $=0.863$ greater than 0.05 which indicates that $\mathrm{H}_{0}$ is accepted and $\mathrm{H}_{\mathrm{a}}$ is rejected. Thus it can be stated that there is no interaction between learning models with gender on student's mathematical problem solving abilities.

The results of this study also have similarities with the results of previous studies [16] which states that both male and female students had almost the same ability in the post-test. Therefore, it is clear that there is no gender dominance in the results obtained for both the experimental and control groups. In the case of problem solving, there is no interaction between learning models with gender on student's mathematical problem solving abilities.

This shows that the learning model with gender does not have a simultaneous effect on problem solving abilities. Only learning models have a significant influence on students' mathematical problem solving abilities. During learning, students do problem-solving activities and students engage in group discussions. The activities carried out continuously lead to the problem solving ability of students who obtain a Problem Based Learning model higher than students who obtain conventional learning, both for male and female students. In other words, differences in students' mathematical problem solving abilities are caused by differences in learning used not because of student gender. 


\section{CONCLUSIONS}

Based on the results of research and discussion, some conclusions can be drawn by referring to the formulation of research problems. We can conclude that there is the effect of Problem-Based Learning model on mathematical problem solving ability of students. In the next section it can be concluded that there is no interaction between learning models (PBL and Conventional) with gender (Male and Female) on students' mathematical problem solving abilities.

\section{ACKNOWLEDGMENT}

The author would like to thank the Advisor for giving directions to improve this research. The author also expressed his gratitude to the Chancellor and the Postgraduate Director of the Universitas Negeri Medan. Thank you also to the principals of SMP 7 Padangsidimpuan, mathematics teachers and experts involved in the research and also to the eighth grade students at SMP 7 Padangsidimpuan.

\section{REFERENCES}

[1] L. Vettleson Jr, "Problem Solving Based Instuction in the High School Mathematics Classroom", Bemidji, Minnesota, USA, 2010, Page. 1-35.

[2] G. Yavuz, C. Arslan, and D. Gulten, "The Perceived Problem Solving Skills Of Primary Mathematics and Primary Social Sciences Prospective Teachers", Procedia Social and Behavioral Sciences, Published by Elsevier Ltd, No. 2, 2010, Pages. 1630-1635.

[3] I. Z. Marchis, "Changing Pre-service Primary School Teachers' Attitude Towards Mathematics by Collaborative Problem Solving", Academic World Education and Research Center, Published by Elsevier Ltd, 2015, Pages. $174-182$.

[4] A. Minarni, "On Eight Grade Students Understanding in Solving Mathematical Problems", Asian Social Science, Vol. 13, No. 12, 2017, Pages. 86-96.

[5] M. Demirel, and M. Dağyar, "Effects of Problem Based Learning on Attitude: a Meta-analysis Study", Eurasia Journal of Mathematics
Science \& Technology Education, Vol. 12, No. 8, 2016, Pages. 21152137.

[6] E. Surya, and E. Syahputra, "Improving High-Level Thinking Skills by Development of Learning PBL Approach on the Learning Mathematics for Senior High School Students", International Education Studies, Vol 10 , No. 8, 2017, Pages. 12-20.

[7] N. Mustaffa, Ismail, Z., Tasir, Nihra, and H. Said, "The Impacts of Implementing Problem-Based Learning (PBL) in Mathematics: A Review of Literature", International Journal of Academic Research in Business and Social Sciences, Vol. 6, No. 12, 2016, Pages. 490-503.

[8] R. I. Arends, "Learning To Teach", Jakarta: Pustaka Pelajar. Translated by Soetjipto, H.P \& M.Soetjipto, Yogyakarta: Pustaka Pelajar., 2008.

[9] D. E. Papalia, and D. F. Ruth, "Menyelami Perkembangan Manusia", Terjemahan Oleh : Fitriani W. H. 2014. Jakarta : Salemba Humanika.

[10] S. E. Kaymakamoğlu, Identification of Interpersonal Problem Solving Skills of Students in The Special Education Department", Elementary Education, Vol. 16, No. 4, 2017, Pages. 1932-1946.

[11] Sugiyono, "Metode Penelitian Pendidikan (Pendekatan Kuantitatif, Kualitatif, dan R\&D)", Bandung: Penerbit Alfabeta, 2015.

[12] Sahyar and R. Fitri, "The Effect of Problem-Based Learning Model (PBL) and Adversity Quotient (AQ) on Problem-Solving Ability", American Journal of Educational Research, Vol. 5, No. 2, 2017, Pages. 179-183.

[13] J. Rokhmawati, E. Djatmika, and L. Wardana, "Implementation of Problem Based Learning Model to Improve Students' Problem Solving Skill and Self-Efficacy (A Study on IX Class Students of SmpMuhammadiyah)", IOSR Journal of Research \& Method in Education (IOSR-JRME), Volume 6, Issue 3 Ver. IV, May-Juny 2016, Pages. 51-55.

[14] Sahyar, R. Sani, and T. Malau, "The Effect of Problem Based Learning (PBL) Model and Self Regulated Learning (SRL) toward Physics Problem Solving Ability (PSA) of Students at Senior High School", American Journal of Educational Research, Vol. 5, No. 3, 2017, Pages. 279-28.

[15] T. Cooper, Bailey, and Briggs, "Gender Differences in Achievement in an InquiryBased Learning Precalculus Course", Mathematics Education, Copyright (C) 2015 by iSER, International Society of Educational Research, Vol. 10, No. 2, 2015, Pages. 97-110.

[16] A. Argaw, B. Haile, B. Ayalew, and S. Kuma, "The Effect of Problem Based Learning (PBL) Instruction on Students' Motivation and Problem Solving Skills of Physics". EURASIA Journal of Mathematics Science and Technology Education, Volume. 13, Issue 3, 2016, Pages. 857-871. 